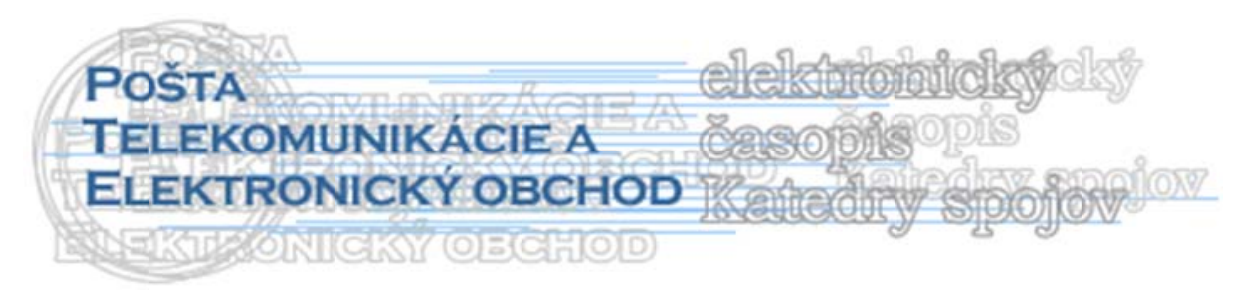

\title{
POROVNANIE PRÍSTUPU K EKONOMICKEJ REGULÁCII LETISKOVÝCH POPLATKOV V SR A ČR
}

\author{
Alena Novák Sedláčková ${ }^{1}$ Lenka Doubravová ${ }^{2}$,
}

\section{Dohl'ad nad poplatkovou politikou v Českej republike}

Súčasná právna úprava civilného letectva a štátnej správy na úseku civilného letectva v Českej Republike je prevažne obsiahnutá v zákone č. 49/1997 Zb, o civilnom letectve a v jeho príslušných vykonávacích vyhláškach ${ }^{3}$. Ministerstvo dopravy vystupuje spolu s Úradom pre civilné letectvo ČR ako najvyšší správny orgán v oblasti civilného letectva. ${ }^{4}$ Právnu úpravu letiskových poplatkov upravuje tiež tento zákon, ktorý hovorí: „Ceny za uživanie letiska a poskytovanie letových prevádzkových služieb zjednávajú prevádzkovatelia letísk a prevádzkovatelia letových prevádzkových služieb podl'a cenových predpisov. " ${ }^{5}$ Dohl'ad, či sú tieto medzinárodné zmluvy pri zjednávaní cien dodržiavané, uskutočňuje Ministerstvo dopravy. Ďalej sú povinný podl’a tohto zákona prevádzkovatelia letísk, leteckých činností a leteckých služieb poskytovat' Ministerstvu dopravy a Úradu štatistické a iné údaje stanovené zvláštnym predpisom ${ }^{6}$, alebo medzinárodnou zmluvou. Ministerstvo dopravy taktiež zabezpečuje vydávanie Leteckej informačnej príručky, ktorej informácie majú vplyv na bezpečnost' leteckej prevádzky.

\section{a) Regulácia letiskových poplatkov v ČR}

Na území Českej republiky sa nachádza 90 civilných letísk. Dňom 1. júla 2004 ukončil svoju činnost' štátny podnik Česká správa letísk a letiská Brno, Ostrava a Karlovy Vary boli prevedené do vlastníctva krajov Juhomoravského, Moravskosliezskeho a Karlovarského. Štát pri týchto letiskách zohráva úlohu regulátora, zákonodarcu a zabezpečuje dohl'ad nad výkonom štátnej moci v oblasti civilného letectva. Jediným letiskom, ktoré zostalo v rukách Českej republiky je akciová spoločnost' Letisko Praha ${ }^{7}$, ktorá

\footnotetext{
${ }^{1}$ Ing.Mgr. Alena Novák Sedláčková, PhD., KLD, F PEDAS, ŽUŽ, alena.sedlackova@fpedas.uniza.sk

${ }^{2}$ bc. Lenka Doubravová, študentka KLD, F PEDAS, ŽUŽ

${ }^{3}$ Vyhláška MDS č. 108/1997 Sb., kterou se provádí zákon č. 49/1997 Sb., o civilním letectví a o změně a doplnění zákona č. 455/1991 Sb., o ţivnostenském podnikání (ţivnostenský zákon), ve znění pozdějších předpisů, ve znění vyhlášky č. 101/1999 Sb., vyhlášky č. 244/2003 Sb., vyhlášky č. 359/2006 Sb. a vyhlášky č.410/2006 Sb. Vyhláška MD č. 17/1966 Sb., o leteckém přepravním řádu, ve znění vyhlášky č. 15/1971 Sb.

Vyhláška MDS č. 222/2000 Sb., o nerovnoměrném rozvrţení pracovní doby některých zaměstnanců v civilním letectví Vyhláška MD č. 410/2006 Sb., o ochraně civilního letectví před protiprávními činy a o změně vyhlášky Ministerstva dopravy a spojů č. 108/1997, kterou se provádí zákon č. 49/1997 Sb., o civilním letectwí a o změně a doplnění zákona č. 455/1991 Sb., o ţivnostenském podnikání (ţivnostenský zákon), ve znění pozdějších předpisů, ve znění pozdějších předpisů

Vyhláška MD č. 466/2006 Sb., o bezpečnostní letové normě

4 Podl'a: Struktura civilního letectví. Ministerstvo dopravy, aktual. máj 2009 [cit. 4. január 2010]. Dostupné na Internete:

http://www.mdcr.cz/NR/rdonlyres/9B432E62-BCBF-409A-98F6-3B8A155AAFF6/0/struktura_cl_cr_kveten_09.pdf

${ }^{5}$ Zákon č. 526/1990 Sb., o cenách, ve znění pozdějších předpisů

${ }^{6}$ Zákon č. 89/1995 Sb., o státní statistické službě

${ }^{7} \mathrm{http}: / /$ www.mdcr.cz/cs/Letecka_doprava/letiste/
} 
vznikla vo februári 2008 v rámci privatizačnej transformácie zo štátneho podniku. Jediným akcionárom tejto akciovej spoločnosti je Česká republika - Ministerstvo financií ČR.

Letisko Praha - Ruzyňe je hlavným letiskom Českej republiky, je jedným z najväčších letísk strednej a východnej Európy. Za rok 2008 získalo ocenenie za najlepšie letisko východnej Európy ${ }^{8}$. Každoročne odbaví približne $11-12$ miliónov cestujúcich. Poplatky na letisku Praha - Ruzyňe v súčasnosti stanovuje prevádzkovatel' letiska a konzultuje ich s leteckými dopravcami. Konzultácie sa uskutočňujú pod dohl'adom Ministerstva dopravy. V prípade sporu medzi prevádzkovatel'mi letiska a dopravcom má dopravca právo obrátit' sa na Úrad pre hospodársku sút’až ( European Commision, 2006). Takýto spôsob regulácie, je napríklad v porovnaní s regulačrným rámcom zavedeným v súvislosti s privatizáciou budapeštianskeho letiska, menej konkrétny a transparentný. To môže mat' nežiadúci vplyv na vnímanie prípadného rizika nepriaznivého intervenčného zásahu zo strany štátu, a tým aj na dosiahnutel'nú predajnú cenu Letiska Praha ${ }^{9}$.

Spomínanou Smernicou európskeho parlamentu z 11. marca 2009 o letiskových poplatkoch sa bude riadit' 67 letísk v Európskej Únii, vrátane pražského letiska Praha Ruzyně, nakol'ko je najväčším letiskom v krajine a minulý rok odbavilo viac ako 12 miliónov cestujúcich. Najväčšia zmena je, že letiská sa budú musiet' o výške letiskových poplatkov radit' s jednotlivými leteckými dopravcami a budú musiet' povinne uvádzat', za aké služby poplatky požadujú. Ak sa výška letiskových poplatkov nebude pozdávat' leteckým dopravcom, budú môct' prizvat' ku riešeniu sporu národného regulátora, ktorý záväzne rozhodne o d'alšom postupe. Predpokladá sa, že zabezpečením transparentnosti a nediskriminácie sa zvýši tlak na letiská a výška poplatkov sa tak bude stanovovat' podl'a nákladov na infraštruktúru a služby. Na druhú stranu Smernica dovol'uje prevádzkovatel'om letísk, aby zvyšovali ceny letiskových poplatkov v prípade, že potrebujú „zafinancovat““ napríklad rozšírenie kapacít, výstavba nového terminálu, či nejaké d’alšie úpravy. Avšak o tomto návrhu je potrebné informovat' cestujúcich ako dlho budú vyššie ceny platit'. Zavedenie nových pravidiel nebude znamenat' pre letisko výraznú zmenu, ked'že ešte pred platnost'ou Smernice začali rokovat' s leteckými dopravcami a s ministerstvom dopravy o výške poplatkov. Aktuálna odletová taxa sa zvýšila po deviatich rokoch zo 488 českých korún na 525 českých korún ${ }^{10}$.

Na zabezpečenie nestranného rozhodovania a riadneho uplatňovania ciel'ov tejto Smernice, by mal byt' v každom členskom štáte zriadený nezávislý dozorný orgán, ktorý by mal mat' k dispozícii všetky potrebné zdroje, či už ide o personál, odbornost' a finančné prostriedky pre plnenie svojich úloh. Práve určenie nezávislého dozorného orgánu bolo t’ažiskovou otázkou a to najmä, či to má byt' Ministerstvo dopravy, ktoré má zatial' pôsobnost' pri dohl'ade v oblasti zjednávanie cien za užívanie letiska, alebo Úrad pre civilné letectvo, ktoré v minulosti prevzalo od Ministerstva dopravy radu činností v oblasti výkonu štátnej správy. Prípadne zriadenie úplne nového správneho úradu, ktorý by dohliadal na oblast' zjednávania cien v leteckej doprave. Následne boli určené a zvážené tieto tri nasledovné varianty:

$\dashv$ variant A „nulová varianta“ - neurčit’ nezávislý dozorný orgán,

$\rightarrow$ variant B - nezávislým dozorným orgánom sa stane Ministerstvo dopravy,

$\downarrow$ variant $\mathrm{C}$ - nezávislým dozorným orgánom sa stane Úrad pre civilné letectvo.

Pri hodnotení prvého variantu A neboli zistené žiadne pozitíva, ktoré by mohol priniest', práve naopak priniesol by intenzívne negatívne dopady voblasti verejných a súkromných rozpočtov. Nulový variant neprináša očakávanú záruku zásady zákazu

\footnotetext{
${ }^{8}$ http://www.prg.aero/cs/o-letisti-praha/o-letisti-praha/

9 Martin Iltis, Stručný přehled ekonomické regulace provozovatelů letišt' v Evropě

${ }^{10} \mathrm{http}: / /$ lis.rlp.cz/ais_data/aip/data/valid/g4-1.pdf
} 
diskriminácie a transparentnosti, požiadavky na vedenie konzultačných jednaní, ako i možnost' zjednávania cien nezávislým dozorným orgánom. S ohl'adom na vyššie uvedené informácie variant A je možné celkom vylúčit'.

Variant B (aby sa nezávislým dozorným orgánom stalo Ministerstvo dopravy) má viacero výhod:

† v prvom rade, by sa splnili záväzky vyplývajúce z členstva Českej republiky v Európskej únii,

† leteckí dopravcovia budú mat' zaručenú zásadu nediskriminácie a zásadu transparentnosti pri zjednávaní cien za užívanie letiska, a tiež budú mat' zaručené pravidelné konzultácie s prevádzkovatel'om letiska vo veci zjednávania ceny za užívanie letiska a ich zmien,

† leteckí dopravcovia a prevádzkovatel' letiska budú mat' možnost' na základe žiadosti obracat' sa o preskúmanie na Ministerstvo dopravy,

† zabezpečenie nezávislosti Ministerstva dopravy na akomkol'vek riadiacom orgáne letiska alebo leteckom dopravcovi.

K nevýhodám variantu $B$ patria nasledovné:

$\rightarrow$ dodatočné odborné nároky na zamestnancov Ministerstva dopravy pri vykonávaní pôsobnosti spojenej s činnost'ou nezávislého dozorného orgánu,

↔ zvýšenie povinnosti prevádzkovatel'a letiska ako aj leteckých dopravcov v oblasti poskytovania údajov spojených s konzultáciami, ktoré sa medzi nimi vedú,

† zvýšenie nároku na verejné rozpočty, a to za účelom posilnenia Ministerstva dopravy, navýšenie počiatočných aj priebežných nákladov.

Pri hodnotení variantu C (kde by sa nezávislým dozorným orgánom stal Úrad pre civilné letectvo ČR) boli zistené pomerne rovnaké výhody ako pri predchádzajúcom variante $\mathrm{B}$, avšak nevýhod pri hodnotení tohto variantu bolo určite viac, okrem vyššie spomenutých to boli najmä tieto:

$\neg$ úrad pre civilné letectvo nemá dlhodobú pôsobnost' v dohl'ade nad zjednávaním cien za užívanie letiska podl'a zákona o civilnom letectve,

† bola by zabezpečená iba čiastočná nezávislost' Úradu pre civilné letectvo z dôvodu celého radu d’alších právomocí Úradu pre civilné letectvo voči prevádzkovatel'om letiska aj leteckým dopravcom,

$\uparrow$ nebolo by možné úplne využit' stavajúce štruktúry verejnej správy.

Následne boli tieto dva varianty zhodnotené a podl'a odborného odhadu najvýhodnejší z hl'adiska finančných nákladov, ktorý štátny rozpočet zat'aží najmenej je variant B a teda sa odporúča, aby sa Ministerstvo dopravy stalo nezávislým dozorným orgánom.

Okrem naplnenia ciel'ov Smernice 2009/12/ES je rovnako dôležitým ciel'om tohto zákona naplnenie záväzkov, ktoré Českej republike plynú z jej členstva v Európskej únii. Transpozičná lehota Smernice 2009/12/ES uplynula dňom 15. marca 2011.

Dňa 10. novembra 2010 vláda schválila návrh zákona, ktorým má byt’ do českého právneho poriadku implementovaná Smernica Európskeho parlamentu a Rady 2009/12/ES z dňa 11 marca 2009 o letiskových poplatkoch. Táto novela zákona sa týka letísk, na ktorých sa odbaví:

b) viac než 5 miliónov cestujúcich v kalendárnom roku, alebo

c) najviac cestujúcich v kalendárnom roku, ak žiadne letisko nespĺn̆a podmienku písmena a). 
Ministerstvo dopravy každoročne zverejní zoznam letísk, ktorých sa tento zákon týka. Jediným letiskom, ktorý splňa vyššie uvedené podmienky (bod A.) je letisko Praha - Ruzyně a nasledujúce ustanovenia sa týkajú výlučne jeho.

Prevádzkovatel' letiska nesmie pri dojednávaní cien za užívanie letiska leteckého dopravcu diskriminovat' a taktiež vyzve každý rok spôsobom umožňujúcim dial'kový prístup leteckých dopravcov, ktorí užívajú prevádzkované letisko, aby sa prihlásili k účasti na prerokovaní návrhu ceny za užívanie letiska (d’alej iba „letiskový cenník“), v stanovenej lehote nie kratšej ako 60 dní. Leteckí dopravcovia, ktorí sa prihlásia na výzvu prevádzkovatel'a letiska sú povinní mu v stanovenej lehote oznámit' údaje z obdobia najmenej dvoch rokov v ročnom členení v nasledujúcom rozsahu:

$\uparrow$ počet prepravených, vrátane prestupujúcich cestujúcich a predpokladaný počet vzletov a pristátí na letisku,

$\rightarrow$ zloženie a využitie lietadlového parku a

† požiadavky na činnosti a vybavenie letiska, ktoré sú zahrnuté do letiskového cenníka.

D̆alšia povinnost' vyplývajúca z tohto zákona pre prevádzkovatel’a letiska, aby každý rok prerokoval letiskový cenník s leteckými dopravcami, ktorí sa prihlásili na jeho výzvu a splnili podmienky a oznámili mu požadované hore uvedené údaje. Letiskový cenník takisto prevádzkovatel' letiska oznámi Ministerstvu dopravy pre prerokovanie. Všetky údaje poskytované leteckými dopravcami a prevádzkovatel'mi letiska sú dôveryhodné a nemôžu sa poskytnuté tretím osobám, bez súhlasu toho, kto ich poskytol. Letecký dopravca môže oznámit' svoje námietky k letiskovému cenníku v stanovenej lehote, ktorú určil prevádzkovatel' letiska, a ten následne tieto pripomienky prerokuje. Prevádzkovatel' letiska po prerokovaní s leteckými dopravcami zverejní letiskový cenník. Ak by nebola dosiahnutá zhoda medzi prevádzkovatel'om letiska a leteckými dopravcami o letiskovom cenníku, prevádzkovatel' letiska zverejní konkrétne dôvody, ktoré ho $\mathrm{k}$ odmietnutiu pripomienok leteckých dopravcov viedli. Tento novelizovaný zákon nadobudol účinnost' dňom 1. marca 2011

\section{d) Prístup k regulácii letiskových poplatkov na Slovensku}

Doteraz nebola na Slovensku uplatňovaná žiadna ekonomická regulácia letiskových poplatkov. Oproti Českej republike sme o niečo pozadu, ked’že Ministerstvo dopravy, výstavby a regionálneho rozvoja Slovenskej republiky „ešte len“ pripravuje konečnú verziu novely zákona ku transpozícii Smernice EP a Rady 2009/12/ES o letiskových poplatkoch, ktorou sa zavádzajú spoločné zásady pre stanovenie výšky jednotlivých poplatkov, resp. systém letiskových poplatkov na území jednotlivých členských krajín, vrátane Slovenskej republiky. Návrhom zákona, ktorým sa mení a doplńa zákon č. 143/1998 Z.z o civilnom letectve a o zmene a doplnení niektorých zákonov v znení neskorších predpisov, sa zriad’uje v súlade so Smernicou dozorný orgán nad systémom letiskových odplát (v terminológii ešte stále nie je odstránená pojmová diskrepancia, pretože na Slovensku sa stále používa a dokonca aj v novele zákona pojem odplata a nie poplatok ako je to v Smernici), ktorého funkciu bude vykonávat' Letecký úrad Slovenskej republiky ${ }^{11}$. Rozsah pôsobnosti pri určovaní odplát na základe Smernice sa týka len letiska M.R.Štefánika v Bratislave, letiska s najväčším počtom vybavených cestujúcich.

V dňoch 22. až 25. novembra bol vykonaný medzinárodný audit Európskej organizácie pre bezpečnost' letovej prevádzky (EUROCONTROL) a v dôsledku výsledkov tohto auditu návrh zákona dopíňa letecký zákon o ustanovenie o určení kompetencie na vykonávanie dozoru a dohl'adu v oblasti navigačných služieb pre Letecký úrad Slovenskej

${ }^{11}$ Dôvodová správa, www.rokovania.sk/File.aspx/Index/Mater-Dokum-131063 
republiky tak, aby bol odstránený nález z auditu v čo najkratšom čase. Návrh zákona nebude mat' žiadny dopad na rozpočet verejnej správy, ani na životné prostredie, alebo sociálne vplyvy. Návrh zákona je v súlade s Ústavou Slovenskej republiky, platným právnym poriadkom Slovenskej republiky, ako aj medzinárodnými zmluvami, ktorými je Slovenská republika viazaná.

Návrh novely leteckého zákona bol predložený dňa 21. februára 2011 a prerokovaný v Legislatívnej rade vlády. Po prerokovaní tohto návrhu zákona vládou SR bude predložený na d’alší legislatívny proces do Národnej rady Slovenskej republiky. Novela leteckého zákona má navrhovanú účinnost' od 1. septembra 2011.

\section{Záver}

Ak bude tento proces úspešný, tak od 1.9.2011 budeme mat' účinnú legislatívu, ktorá je aplikáciou európskeho práva. Je nutné poukázat' na fakt, že novela zákona prichádza 6 mesiacov neskôr než bolo požadované EÚ a hlavne, že k tomuto zákonu neprebehla žiadna verejná diskusia ako je to $\mathrm{v}$ súčasnosti na Slovensku bežné a ani nie sú známe dôvody rozhodnutia riešit' danú situáciu týmto spôsobom tak, ako to má v dôvodovej správe stanovená ČR. Na základe vyššie uvedených informácií si ešte dovol'ujeme poukázat’ na fakt, že Smernica požadovala vytvorenie alebo garanciu ustanovenia nezávislého dozorného orgánu, ktorý bude dohliadat' na správnost' procesu stanovenia letiskových poplatkov. Tak ako sme už uviedli, v SR má túto úlohu vykonávat' Letecký úrad SR, ktorý bol vyhodnotený Ministerstvom dopravy, výstavby a regionálneho rozvoja (MDVaRR) ako nezávislý. Je ale otázne, ako sme schopný túto nezávislost' dokázat', ked' Smernica požaduje nezávislost' tohto orgánu od orgánu, ktorý má spravovat' vlastnícke a majetkové vzt’ahy letiska, ak je vo vlastníctve členského štátu, a to v prípade SR má v kompetencii MDVaRR. No toto isté Ministerstvo resp. jeho minister menuje podl'a zákona č. 143/1998 Z.z. o civilnom letectve riaditel'a Leteckého úradu SR a takisto LÚ SR vznikol na základe Rozhodnutia ministra dopravy pôšt a telekomunikácii (pôvodný názov MDVaRR) č. 74/98 z 26. júna 1998 a jeho činnost' je vymedzená zriad'ovacou listinou. Dôležité je poukázat' aj na fakt, že Letecký úrad SR je na štátny rozpočet naviazaný prostredníctvom MDVaRR. A práve $\mathrm{v}$ tejto chvíli si dovol'ujeme upozornit', že práve tieto fakty by mohli mat' negatívny dopad na vyhodnotenie Európskej Komisie, ktorá má do roku 2013 zhodnotit' správnost' aplikácie Smernice a predložit' správu Európskemu parlamentu a Rade.

\section{Literatúra}

[1] Zákon č. 49/1997 Zb,. o civilnom letectve a jeho príslušné vykonávacie vyhlášky

[2] Zákon č. 143/1998 Z.z. o civilnom letectve v znení neskorších predpisov

[3] http://www.mdcr.cz/NR Struktura civilního letectví. Ministerstvo dopravy

[4] Zákon č. 526/1990 Sb., o cenách, ve znění pozdějších předpisů

[5] Zákon č. 89/1995 Sb., o státní statistické službě

[6] http://www.mdcr.cz/cs/Letecka_doprava/letiste/

[7] http://www.prg.aero/cs/o-letisti-praha/o-letisti-praha/ 